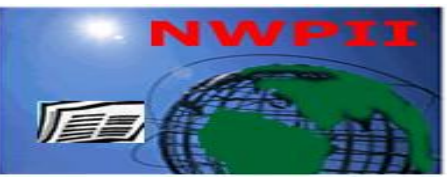

American Journal of Biomedical Sciences

ISSN: 1937-9080

nwpii.com/ajbms

\title{
Stabilizing Ability and Anti-sickling Potentials of Ganoderma Lucidum Decoction Extract on Human HbS Erythrocytes Membrane
}

\author{
Reginald Chibueze Ohiri and Eka Bassey Essien
}

Department of Biochemistry, Faculty of science, University of Port Harcourt. P. M. B. 5323, East-West Road, Choba, Rivers State, Nigeria.

"Corresponding Author

Reginald Chibueze Ohiri

Department of Biochemistry, Faculty of science

University of Port Harcourt. P. M. B. 5323, East-West Road, Choba

Rivers State

Nigeria

Email: raycohiri@yahoo.com, reginald.ohiri@uniport.edu.ng

Tel:+2348038808077

Received:07 October 2018; | Revised:09 November 2018; | Accepted: 10 December 2018

\begin{abstract}
Anti-sickling properties of Ganoderma lucidum decoction extract were studied using human HbS erythrocytes. The \% lysis, median corpuscular fragility, \% stability, polymerisation rate and morphological deformations were determined. The lowest \% lysis of $(6.76+1.63 \%$ and $6.15+1.96 \%)$ were observed in cells treated with $5 \mathrm{mg} / \mathrm{ml}$ of extract at $7.0 \mathrm{~g} / 1$ and $9.0 \mathrm{~g} / 1$ saline concentrations, while increase in median corpuscular fragility of the erythrocytes were observed, with values of $5.33+0.41 \mathrm{~g} / 100 \mathrm{~g}, 5.99+0.83$ $\mathrm{g} / 100 \mathrm{~g}$ and $6.08+0.51 \mathrm{~g} / 100 \mathrm{~g}$ for $5 \mathrm{mg} / \mathrm{ml}, 10 \mathrm{mg} / \mathrm{ml}$ and $15 \mathrm{mg} / \mathrm{ml}$ of extract. Erythrocytes percentage stability also increased with values of $12.92+0.86 \%, 26.91+1.05 \%$ and $28.81+0.94 \%$ for $5 \mathrm{mg} / \mathrm{ml}, 10$ $\mathrm{mg} / \mathrm{ml}$ and $15 \mathrm{mg} / \mathrm{ml}$ of extract, while a pronounced decrease in haemoglobin polymerisation rate was observed at $15 \mathrm{mg} / \mathrm{ml}$ of extract from the 2 nd to the 3 rd minute of analysis with values $0.78+0.12 \%, 0.47+$ $0.07 \%$ and $0.58+0.09 \%$ for $2.0,2.5$ and 3.0 minutes. The lowest erythrocytes morphological deformity score was observed at $15.0 \mathrm{mg} / \mathrm{ml}$ extract with values of $80.00+3.70 \%, 56.00+2.80 \%$ and $44.00+2.20 \%$ at $0.0,5.0$ and 10.0 minutes respectively.
\end{abstract}

Keywords: Ganoderma lucidum, Decoction extract, Erythrocytes, Stability, Polymerization

\section{Introduction}

Sickle cell disease is a disorder of the haemoglobin that alters the normal morphology of the erythrocytes thereby producing a crescent shaped or sickled erythrocyte. At the molecular level, this inheritable disease is caused by a mutation of a nucleotide of the $\beta$-globin gene from a GAG codon that translates to glutamic acid to a GTG codon which subsequently transcribes into a GUG and translates to valine. This tantamount to 
substitution of glutamic acid at position 6 with valine (if the starting methionine in amino acid numbering of a protein was skipped) or at position 7 (if the methionine was counted as the first amino acid). Though sickle cell disease is more prevalent (about $80 \%$ ) in sub-Sahara Africa ${ }^{[1]}$, its occurrence in parts of India, the Arabian peninsula, and among people of African origin living in other parts of the world has been reported ${ }^{[2]}$. Different health problems such as attacks of pain (sickle-cell crisis), anaemia, bacterial infections and stroke have been associated with sickle cell disease ${ }^{[3]}$. To a large extent, these disease conditions have been managed with vaccination, pain medication, high fluid intake, preventive antibiotics and folic acid supplementation ${ }^{[4,5]}$. While advanced measure such as blood transfusion, administration of hydroxycarbamide [5] and bone marrow transplantation [6] have been taken into consideration in the cause of management and treatment of sickle cell anaemia. Irrespective of these advances in sickle cell management and treatment, the mortality rate increased from 113,000 in 1990 to 176,000 in $2013^{\text {[7] }}$, thereby necessitating the need for more research.

The relevance and rich medicinal history of most mushrooms demands for researches using extracts of such mushrooms in the treatment and management of notable disease conditions such as sickle cell anaemia. Though some of these mushrooms are still very relevant in traditional medicine for treatment of diseases mainly of microbial related infections ${ }^{[8]}$, most of their isolates have shown potential anti-inflammatory and antidiabetic properties in preliminary studies ${ }^{[9]}$. Some of their polysaccharides, glycoproteins, proteoglycans and other components are presently under basic research for their potential to modulate immune system responses and inhibit tumor growth [8]. One notable mushroom with a long medicinal history is the Gernoderma. lucidum (also known as Reishi or Lingzhi mushroom). G. lucidum is a polypore mushroom that grows on wood, and many of its known 80 species are from tropical regions ${ }^{[10]}$. Scientific studies on the extracts from the fruiting body, mycelia and spores of this mushroom have shown its ability to boost the immune system, work against herpes virus, reduce cholesterol level and stop cell proliferation ${ }^{[11]}$. Yuen and Gohel ${ }^{[12]}$ and Zaidman et al., [13] also reported that most polysaccharides and triterpenes, extracted from G. lucidum exhibits chemopreventive and tumoricidal effects. This study will determine the possibility of Ganoderma lucidum decoction extract to elicit membrane stabilization and anti-sickling potentials on Human HbS erythrocytes membrane.

\section{Experimental section}

\subsection{Sample collection, preparation and extraction}

Fresh G. lucidum was obtained from its natural environment within the University of Port Harcourt in Rivers State, South-south Nigeria. A quantity of the mushroom $(3.5 \mathrm{~kg})$ was thoroughly washed with distilled water, sliced with a sterilized knife and air dried for a period of one (1) week in a clean dust free environment. The dried samples were ground using a Thomas Scientific, (Model 4) Wiley's mill until a fine smooth powder was obtained. Five hundred grams of ground G. lucidum was weighed out and $0.5 \mathrm{dm} 3$ of distilled water was added and mixed properly. The mixture was boiled at 100 0C for $30 \mathrm{~min}$. and after $2 \mathrm{hrs}$ of cooling, the mixture was filtered and the filtrate was concentrated to dryness using a Secador 4.0 autodesicator.

\subsection{Preparation of $\boldsymbol{G}$. lucidum sample solution}

A volume of $15 \mathrm{mg} / \mathrm{ml}$ stock solution of $G$. lucidum decoction extract solution was prepared by dissolving $0.375 \mathrm{~g}$ of dried decoction extract of $G$. lucidum in deionized water and adjusted to 0.25 $\mathrm{dm} 3$, Volumes of $5.0 \mathrm{mg} / \mathrm{ml}$ and $10.0 \mathrm{mg} / \mathrm{ml}$ were obtained from the stock solution via serial dilution.

\subsection{Collection and preparation of blood sample}

A volume of $5.0 \mathrm{ml}$ of $\mathrm{HbS}$ venous blood sample was collected by venipuncture from an apparently healthy volunteer using a sterilized 5.0 $\mathrm{ml}$ syringe. The blood was immediately transferred into ethylenediaminetetraacetic acid (EDTA) sample bottle. Exactly $1.0 \mathrm{ml}$ of the blood sample was introduced into a $10.0 \mathrm{ml}$ test tube and $5.0 \mathrm{ml}$ of $0.9 \%$ physiological saline was added. The erythrocyte suspension was gently mixed and centrifuged in a Sorvall Instruments GLC-4 General Laboratory Centrifuge at 2500 rotation per minute (r.p.m) for $10 \mathrm{~min}$. and the supernatant was gently removed using a Pasteur pipette. The procedure was repeated twice and the washed erythrocytes were 
suspended in physiological saline and use for analysis within 2 hours.

\subsection{Determination of osmotic fragility of erythrocytes}

Erythrocyte osmotic fragility was determined using the method described by Dacie et al., ${ }^{[14]}$. A volume of $5.0 \mathrm{ml}$ each of saline solutions 9.0, 7.0, 6.0, 5.0, 4.0, 3.0, 2.0 and $1.0 \mathrm{~g} / 1 \mathrm{NaCl}$ were placed into $1 \mathrm{x} 12 \mathrm{~cm}$ labeled test tubes, while $5.0 \mathrm{ml}$ of deionized water was introduced into the control test tube. Exactly of $0.5 \mathrm{ml}$ of $5.0 \mathrm{mg} / \mathrm{ml}$ of G. lucidum extract was added into all the test tubes and $50.0 \mu 1$ of properly mixed fresh blood was added into each of the tubes. The mixtures were carefully and properly mixed immediately to avoid foaming. After incubation at room temperature for $30 \mathrm{~min}$., the mixtures were carefully mixed again and centrifuged at $1200 \mathrm{rpm}$ for 5 mins. Using the supernatant from test tube 1 (osmotically equivalent to $9.0 \mathrm{~g} / \mathrm{l} \mathrm{NaCl}$ ) as the blank, the supernatants were collected and the quantity of hemoglobin released was colorimetrically determined at $540 \mathrm{~nm}$ using a Labtech single beam 295 Advanced Microprocessor UV-VIS spectrophotometer. This procedure was repeated for $10.0 \mathrm{mg} / \mathrm{ml}$ and $15.0 \mathrm{mg} / \mathrm{ml}$ of $G$. lucidum extract. The \% lyses was calculated and the results were plotted against the $\mathrm{NaCl}$ concentration using the absorbance of deionized water (control test tube) as $100 \%$ lysis point.

$\%$ lysis $=\{$ As $/$ Ac $\} X 100$.

Where:As $=$ absorbance of sample.

Ac $=$ absorbance of control.

The median corpuscular fraction (MCF) at $50 \%$ lysis was extrapolated as described by Dewey et al., ${ }^{[15]}$ and Krogmeier et al., ${ }^{[16]}$ and the $\%$ stability was calculated using the method described by Chikezie et al., ${ }^{[17]}$ with slight modification.

$\%$ stability $=\frac{\text { mcf }_{t}-m c f_{c}}{m c f_{c}} \quad X \quad 100$.

Where:mcft=Median corpuscular fraction of test. $\mathrm{mcfc}=$ Median corpuscular fraction of control.

\subsection{Determination of haemoglobin polymerization rate}

Haemoglobin polymerization rate was determined using the method of Noguchi and Schechter, [18], as modified by Iwu et al., [19], A volume of $4.40 \mathrm{ml}$ of freshly prepared $2 \% \mathrm{w} / \mathrm{v}$ Sodium metabisulphite ( $\mathrm{Na} 2 \mathrm{~S} 2 \mathrm{O} 2)$ was placed into a $5.0 \mathrm{ml}$ plain sample bottle and $0.1 \mathrm{ml}$ of washed human $\mathrm{Hbs}$ erythrocyte haemolysate was added and mixed with $0.5 \mathrm{ml}$ of $5.0 \mathrm{mg} / \mathrm{ml}$ of $G$. lucidium extract, while $0.5 \mathrm{ml}$ of deionized water was added in the control bottle. The mixture was gently transferred into a $1 \mathrm{~cm}$ cuvette and the absorbance at $700 \mathrm{~nm}$ was taken at $30 \mathrm{sec}$. interval for $3 \mathrm{~min}$. using a Labtech single beam 295 Advanced Microprocessor UV-VIS spectrophotometer. This procedure was repeated using $10.0 \mathrm{mg} / \mathrm{ml}$ and 15.0 $\mathrm{mg} / \mathrm{ml}$ of $\mathrm{G}$. lucidum extract. The polymerization rate was calculated and expressed as percentages.

Polymerization rate $\left(P_{R}\right)=\underline{a_{f}} \underline{n}-a_{i} 0$

$t_{n}$

Where:afn $=$ Final absorbance at time $(\mathrm{t})=\mathrm{n}$.

ai0 $=$ Initial absorbance at time $(\mathrm{t})=0$.

th $=$ Time of reaction in minutes.

\subsection{Erythrocytes culturing and smear preparation}

This was carried out using the method described by Daland and Castle ${ }^{[20]}$, exactly $0.1 \mathrm{ml}$ of washed human $\mathrm{HbS}$ erythrocytes was placed in a test tube and mixed with $0.5 \mathrm{ml}$ of $5.0 \mathrm{mg} / \mathrm{ml}$ of $\mathrm{G}$. lucidium extract, while $0.5 \mathrm{ml}$ of deionized water was added to the control. Smear of $10.0 \mu 1$ of the mixture was prepared according to the method described by Brown [21], where a monolayer of erythrocytes was obtained by carefully dispersing a drop of the suspended erythrocytes placed on one end of a slide over the slide' $\mathrm{s}$ length using a spreader slide. The feathered edge of the monolayer was viewed at $0.0,5.0$ and 10.0 mins. at X400 magnification under an Olympus CX31RTSF microscope and snapped using Olympus E330ADU1.2X 6K13883 camera. This procedure was repeated for $10.0 \mathrm{mg} / \mathrm{ml}$ and $15.0 \mathrm{mg} / \mathrm{ml}$ of $\mathrm{G}$. lucidium extract. 


\subsection{Statistical analysis}

The mean + standard deviations and One Way Analysis of Variance (ANOVA) were calculated electronically using International Business Machine (IBM) Statistical Program for Social Sciences (SPSS) 19 statistics software (SPSS Inc Chicago) at 95\% confidence level, using post hoc Duncan ${ }^{[22]}$, multiple range test of significance.

\section{Results}

The result of this study showed a decrease in lysis rate of the erythrocyte as the concentration of

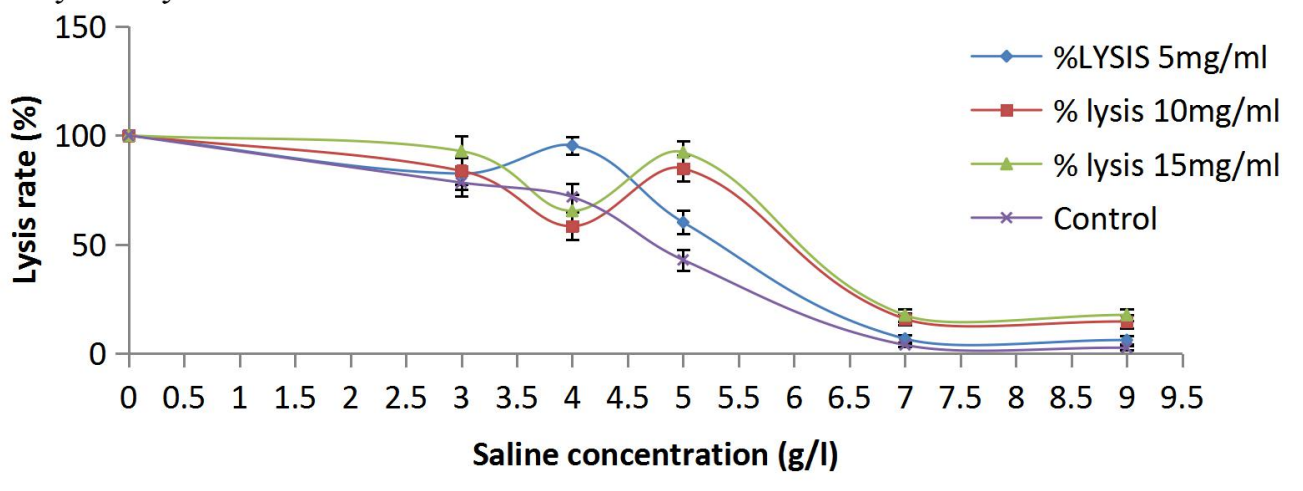

Fig.1. Percentage lysis of erythrocytes treated with different concentrations of G. lucidum decoction extract

A continuous increase in median corpuscular fragility of the erythrocyte was observed as the concentration of the G. lucidum extract increases. Values of $5.33+0.41 \mathrm{~g} / 100 \mathrm{~g}, 5.99+0.83 \mathrm{~g} / 100 \mathrm{~g}$ the buffered saline increases. Lowest values of 6.76 $+1.63 \%$ and $6.15+1.96 \%$ were observed for 5.0 $\mathrm{mg} / \mathrm{ml}$ of G. lucidum extract concentration at $7.0 \mathrm{~g} / 1$ and $9.0 \mathrm{~g} / \mathrm{l}$ of saline concentration, while 10.0 $\mathrm{mg} / \mathrm{ml}$ of G. lucidum extract concentration had $15.87+2.71 \%$ and $14.62+3.11 \%$ at $7.0 \mathrm{~g} / 1$ and $9.0 \mathrm{~g} / \mathrm{l}$ of buffered saline concentration. Values of $17.56+2.74 \%$ and $17.70+2.61 \%$ were observed for $15.0 \mathrm{mg} / \mathrm{ml}$ of G. lucidum extract concentration at $7.0 \mathrm{~g} / 1$ and $9.0 \mathrm{~g} / 1$ of buffered saline concentration, while the control had $3.90+0.59 \%$ and $2.60+0.83 \%$ at $7.0 \mathrm{~g} / 1$ and $9.0 \mathrm{~g} / 1$ of saline concentration (Fig. 1).

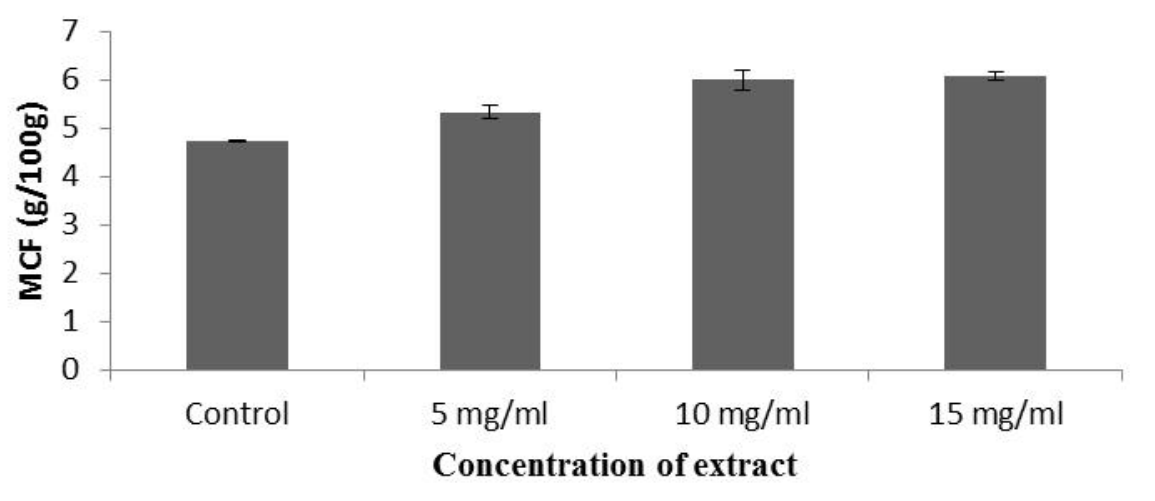

Fig.2. Median corpuscular fragility (MCF) of erythrocytes treated with different concentrations of G. lucidum decoction extract

The stability rate (\%) of the erythrocytes also increased as the concentration of G. lucidum extract increases with values of $12.92+0.86 \%, 26.91+$ $1.05 \%$ and $28.81+0.94 \%$ for $5.0 \mathrm{mg} / \mathrm{ml}$, and $6.08+0.51 \mathrm{~g} / 100 \mathrm{~g}$ were observed for $5.0 \mathrm{mg} / \mathrm{ml}$, $10.0 \mathrm{mg} / \mathrm{ml}$ and $15.0 \mathrm{mg} / \mathrm{ml}$ of G. lucidum extract respectively, while the control had a median corpuscular fragility $4.72+0.21 \mathrm{~g} / 100 \mathrm{~g}$ (Fig. 2). 


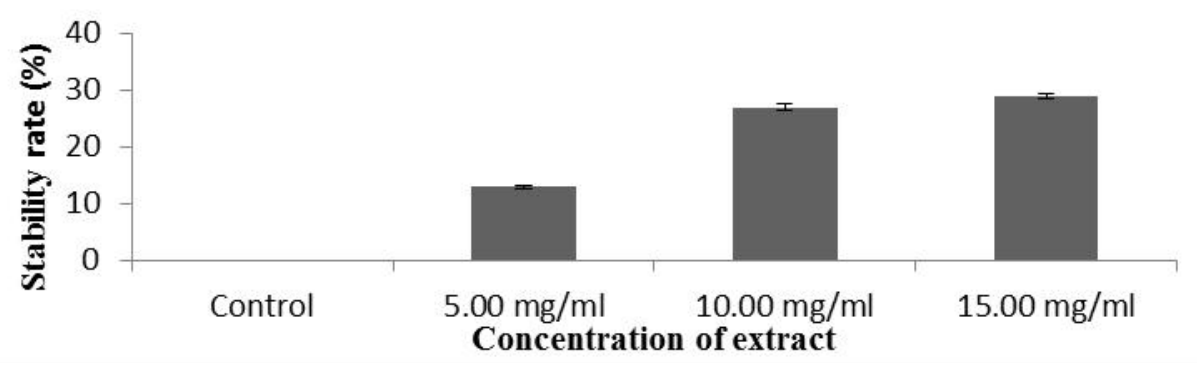

Fig.3. Stability rate (\%) of erythrocytes treated with different concentrations of G. lucidum decoction extract

A decrease in haemoglobin polymerisation was observed mainly from the second to the third minute with values of $2.27+0.64 \%, 1.57+0.49 \%$ and $1.43+0.23 \%$ at $2.0 \mathrm{~min}, 2.5 \mathrm{~min}$. and $3.0 \mathrm{~min}$ for

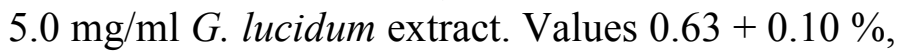
$0.48+0.08 \%$ and $0.58+0.11 \%$ at $2.0 \mathrm{~min}, 2.5 \mathrm{~min}$.

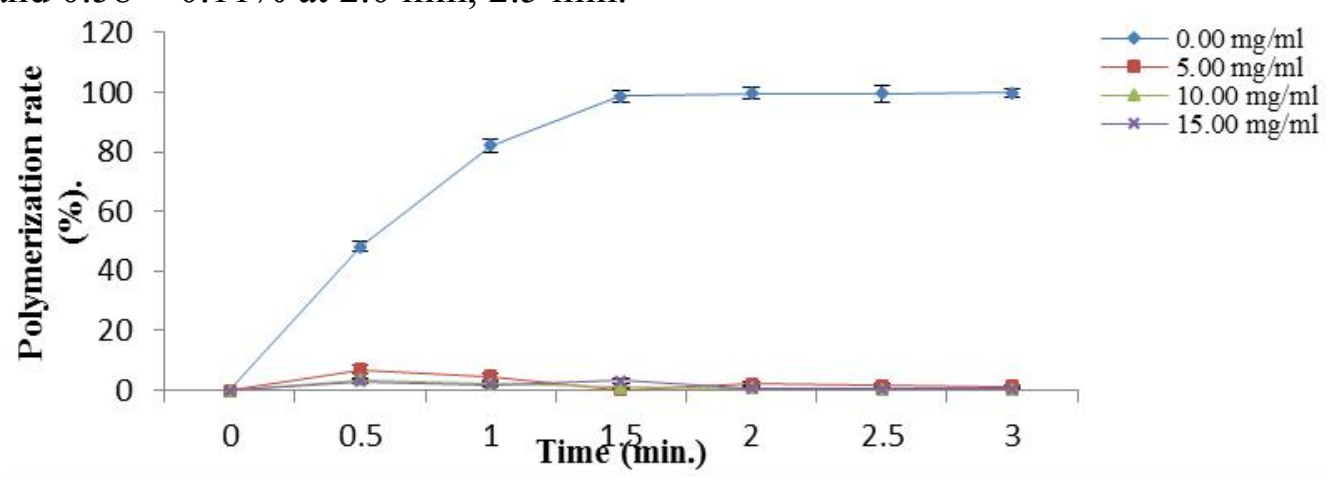

Fig.4. Polymerization rate (\%) of erythrocytes treated with different concentrations of G. lucidum decoction extract

The lowest morphological deformity scores were observed in the erythrocytes cultured with $15.0 \mathrm{mg} / \mathrm{ml}$ of $\mathrm{G}$. lucidum extract with values of $80.00+3.70 \%, 56.00+2.80 \%$ and $44.00+2.20 \%$ at $0.0 \mathrm{~min}$., $5.0 \mathrm{~min}$. and $10.0 \mathrm{~min}$. respectively, while those cultured with $10.0 \mathrm{mg} / \mathrm{ml}$ of G. lucidum extract had values of $82.00+2.90 \%, 78.00+$ $3.40 \%$ and $71.00+4.80 \%$ at $0.0 \mathrm{~min} ., 5.0 \mathrm{~min}$. and and $3.0 \mathrm{~min}$ were observed for $10.0 \mathrm{mg} / \mathrm{ml} G$. lucidum extract, while $15.0 \mathrm{mg} / \mathrm{ml}$ of $G$. lucidum extract had $0.78+0.12 \%, 0.47+0.07 \%$ and $0.58+$ $0.09 \%$ at $2.0 \mathrm{~min}, 2.5 \mathrm{~min}$. and $3.0 \mathrm{~min}$. respectively (Fig. 4).

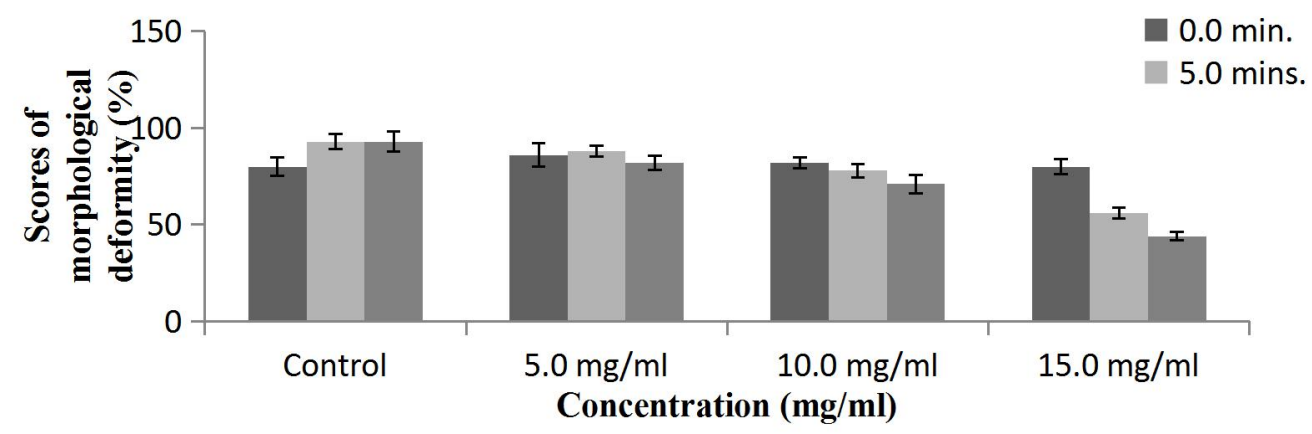

Fig.5. Scores of morphological deformities (\%) of erythrocytes treatment with different concentrations of $G$. lucidum decoction extract 


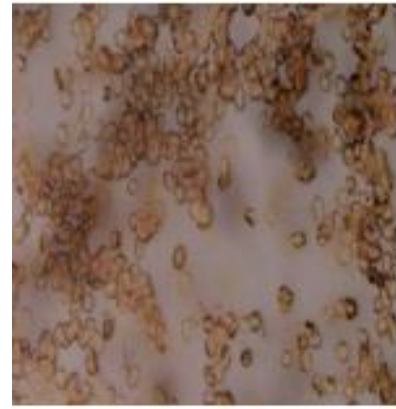

(i)

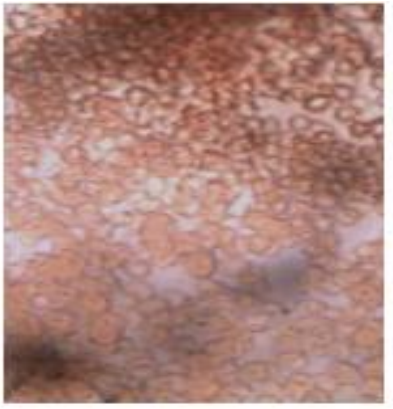

(ii)

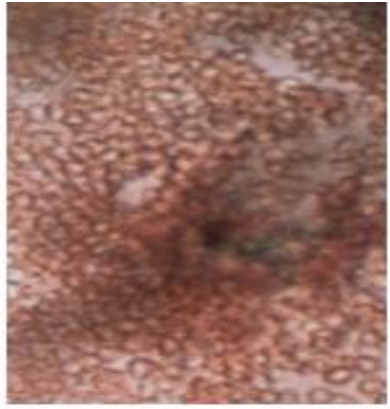

(iii)

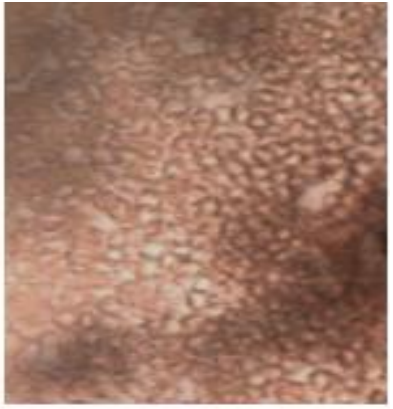

(iv)

Fig.6a. Morphology of erythrocytes at $0.0 \mathrm{~min}$. of treatment with different concentrations of G. lucidum decoction extract (Magnification. X400)

(i). Control (showing clusters of sickled, treated with $10.0 \mathrm{mg} / \mathrm{ml}$ of G. lucidum extract slightly-sickled and slightly normal erythrocytes). (showing sickled, slightly-sickled and few normal (ii). Erythrocytes treated with $5.0 \mathrm{mg} / \mathrm{ml}$ of $G$. lucidum extract (showing clusters of sickled and slightly-sickled erythrocytes). (iii). Erythrocytes erythrocytes). (iv). Erythrocytes treated with 15.0 $\mathrm{mg} / \mathrm{ml}$ of G. lucidum extract (showing sickled, slightly sickled and few normal erythrocytes) .

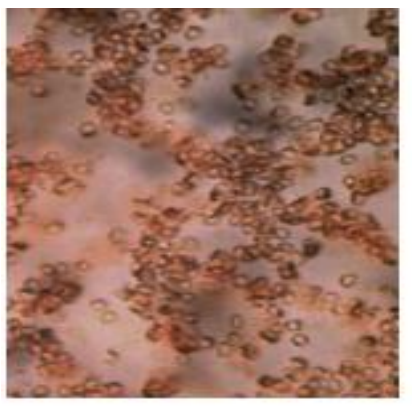

(i)

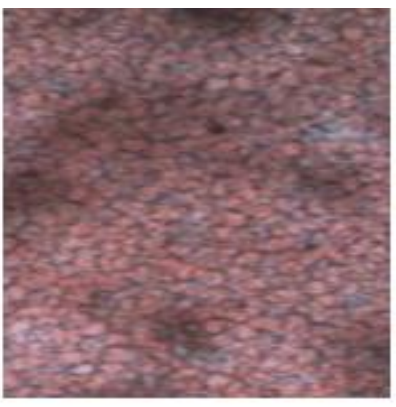

(ii)

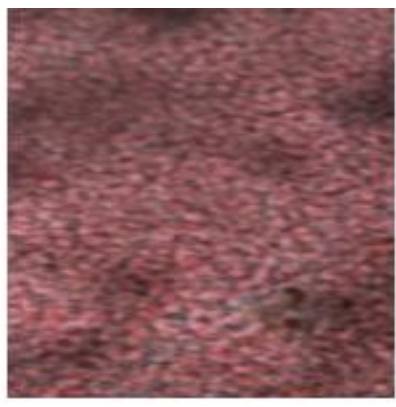

(iii)

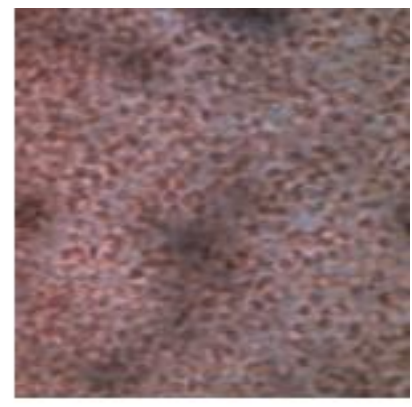

(iv)

Fig. 6b. Morphology of erythrocytes at 5.0 min. of treatment with different concentrations of G. lucidum decoction extract (Magnification. X400)

(i). Control (showing clusters of sickled, slightly-sickled and slightly normal erythrocytes). (ii). Erythrocytes treated with $5.0 \mathrm{mg} / \mathrm{ml}$ of $G$. lucidum extract (showing sickled, slightly-sickled and morphologically deformed erythrocytes). (iii). Erythrocytes treated with $10.0 \mathrm{mg} / \mathrm{ml}$ of G. lucidum

extract (showing sickled, slightly-sickled and morphologically deformed erythrocytes). (iv). Erythrocytes treated with $15.0 \mathrm{mg} / \mathrm{ml}$ of G. lucidum extract (showing few slightly-sickled and normal morphologically stable erythrocytes).

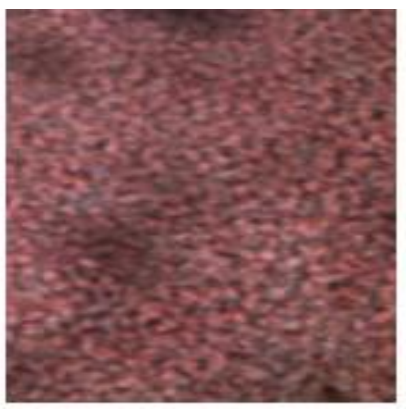

(iii)

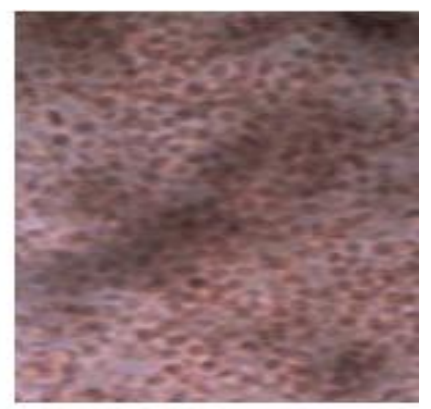

(iv)

(i)

(ii)

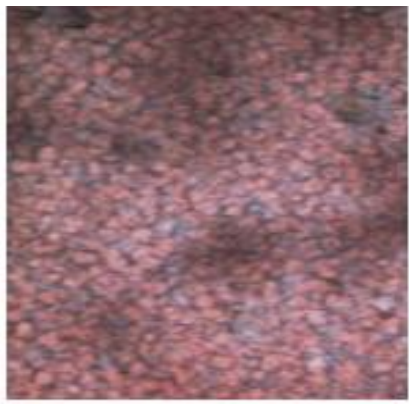

Fig .6c. Morphology of erythrocytes at 10.0 min.of treatment with different concentrations of $\mathbf{G}$. lucidum decoction extract (Magnification. X400) 
(i). Control (showing clusters of sickled, semisickled and few normal erythrocytes). (ii). Erythrocytes treated with $5.0 \mathrm{mg} / \mathrm{ml}$ of G. lucidum extract (showing sickled, slightly-sickled and morphologically deformed erythrocytes) (iii). Erythrocytes treated with $10.0 \mathrm{mg} / \mathrm{ml}$ of G. lucidum extract (showing slightly-sickled and few normal erythrocytes). (iv). Erythrocytes treated with 15.0 $\mathrm{mg} / \mathrm{ml}$ of $\mathrm{G}$. lucidum extract (showing normal and morphologically stable erythrocytes).

\section{Discussion}

The structural transformation of the erythrocytes has been an important phenomenon that aids blood circulation. Mohandas and Fea ${ }^{[23]}$, reported the ability of the erythrocytes to move through successive stages that spans between biconcave discocyte and complete spherical form. Erythrocytes suspended in hypotonic medium undergo irreversible transformations that tantamount into hemolysis after entering the spherical phase ${ }^{[24]}$. The sigmoid shape of the normal (AA) \% lysis (osmotic fragility) curve observed in fig. 1 indicates that normal erythrocytes may vary in their resistance to hypotonic solutions. The non-significant decrease $(\mathrm{p}<0.05)$ in lysis rate observed when $10.0 \mathrm{mg} / \mathrm{ml}$ and $15.0 \mathrm{mg} / \mathrm{ml}$ of mushroom extract was added to the erythrocytes suspended in $4.0 \mathrm{~g} / 1$ saline concentration show the ability of this mushroom extract to minimally reduce hemolysis at such hypotonic saline concentration. This marginal decrease indicates that the decoction extract of this mushroom may have either stabilized the membrane composition or preserved the integrity of the cells at such saline concentration but was unable to sustain such stability at higher saline concentration and even at the isotonic concentration of $9.0 \mathrm{~g} / \mathrm{l}$. This corroborates the works of [25], [26], [27], where cell membrane composition, membrane integrity and cells' sizes were reported to affect osmotic fragility.

The significant increase $(\mathrm{p}<0.05)$ in stability rate observed when $5.0 \mathrm{mg} / \mathrm{ml}, 10.0 \mathrm{mg} / \mathrm{ml}$ and $15.0 \mathrm{mg} / \mathrm{ml}$ of mushroom extract was added to the erythrocytes (see fig. 3) shows the extracts of this mushroom may alter the erythrocyte membrane, thereby enhancing the passage of sodium out of the erythrocytes, which may tantamount to increase in percentage stability. The significant decrease in haemoglobin polymerization rate $(p<0.05)$ observed in this study (see fig. 4) shows that some components of this mushroom may have the ability to enhance the binding and transportation of oxygen by reversing the deoxygenating effect of sodium metabisulphite thereby preserving or stabilizing the haemoglobin structure. The low morphological deformity scores observed in the erythrocytes cultured with $15.0 \mathrm{mg} / \mathrm{ml}$ and 10.0 $\mathrm{mg} / \mathrm{ml}$ of G. lucidum extract for $5.0 \mathrm{~min}$. and 10.0 min. (see fig. 5) reveals the ability of this mushroom extract to stabilize the structure of the erythrocytes. The morphologically stable erythrocytes observed at $5.0 \mathrm{~min}$. and $10.0 \mathrm{~min}$. when cultured with $15.0 \mathrm{mg} / \mathrm{ml}$ of the extract (see figs. $6 a-6 c)$ indicates that compound(s) present in the extract of this mushroom can potentially reduce and possibly reverse erythrocyte sickling in a concentration and time dependent manner. As stated earlier, this low morphological deformity indicates that a certain non-volatile component(s) of this mushroom may have the ability to reverse and sustain the erythrocyte membrane integrity, thereby enhancing erythrocyte capillary passage and possibly reducing sickle cell attributed pains and related crisis.

\section{Conclusion}

The reversal and stabilization of erythrocyte membrane integrity and morphology observed in this study is a clear indication that non-volatile component(s) present in the decoction extract of this mushroom may be responsible for its antisickling properties and isolation of this active component(s) may be of good use in the amelioration sickle cell anaemia and its associated crises.

\section{References}

1 Rees DC, Williams TN, Gladwin MT. Sicklecell disease. Lancet 2010; 376(9757): 20182031 DOI: $10.1016 / \mathrm{S} 0140-6736(10) 61029-\mathrm{X}$

2 Elzouki, A. Y. Textbook of clinical pediatrics (2ed.). Springer. Berlin Germany, 2012, p. 2950. 
3 What Are the Signs and Symptoms of Sickle Cell Disease? National Heart, Lung, and Blood Institute. (NHLBI). 2015b, Retrieved 8 March 2016.

4 Sickle-cell disease and other haemoglobin disorders.World Health Organization (WHO).2011, Fact sheet no. 308.

5 How Is Sickle Cell Disease Treated?. National Heart, Lung, and Blood Institute. National Heart, Lung, and Blood Institute. (NHLBI).2015c, June 12, 2015.

6 What Is Sickle Cell Disease?National Heart, Lung, and Blood Institute. (NHLBI). 2015a, Retrieved 8 March 2016.

7 Mortality GBD, Causes of Death C. Global, regional, and national age-sex specific allcause and cause-specific mortality for 240 causes of death, 1990-2013: a systematic analysis for the Global Burden of Disease Study 2013. Lancet 2015; 385(9963): 117-171 DOI: $10.1016 / \mathrm{S} 0140-6736(14) 61682-2$

8 Borchers AT, Krishnamurthy A, Keen CL, Meyers FJ, Gershwin ME. The immunobiology of mushrooms. Exp Biol Med (Maywood) 2008; 233(3): 259-276 DOI: 10.3181/0708-MR-227

9 Lull C, Wichers HJ, Savelkoul HF. Antiinflammatory and immunomodulating properties of fungal metabolites. Mediators Inflamm 2005; 2005(2): 63-80 DOI: 10.1155/MI.2005.63

10 Kirk, P. M.; Cannon, P. F.; Minter, D. W.; Stalpers, J. A. Dictionary of the Fungi. 10th ed. Wallingford: $\boldsymbol{C A B I} .2009$, p. 272.

11 Engelbrecht, K.; Volk, T. Ganoderma lucidum, Reishi or Ling Zhi, a fungus used in oriental medicine. Tom Volk's Fungus of the Month for March 2005.

12 Yuen JW, Gohel MD. Anticancer effects of Ganoderma lucidum: a review of scientific evidence. Nutr Cancer 2005; 53(1): 11-17 DOI: $10.1207 / \mathrm{s} 15327914 \mathrm{nc} 53012$

13 Zaidman BZ, Yassin M, Mahajna J, Wasser SP. Medicinal mushroom modulators of molecular targets as cancer therapeutics. Appl Microbiol Biotechnol 2005; 67(4): 453-468 DOI: $\underline{10.1007 / \mathrm{s} 00253-004-1787-\mathrm{Z}}$

14 Dacie, J. V.; Lewis, S. M.; Luzzatto, L. Investigation of the hereditary haemolytic anaemia membrane and enzyme abnormalities in practical haematology, Churchill Livingstone, New York. 1981, p. 234 - 238.

15 Dewey MJ, Brown JL, Nallaseth FS. Genetic differences in red cell osmotic fragility: analysis in allophenic mice. Blood 1982; 59(5): 986-989

16 Krogmeier, D. E.; Mao, I. L.; Bergen, W. G. Genetic and nongenetic effects of erythrocyte osmotic fragility in lactating Holstein Cows and its association with yield traits. Jour. Diary Sci., 1993, 76: 1994 - 2000.

17 Chikezie, P. C.; Chikezie, C. M.; Nwanegwo, C. O. Osmotic fragility index of chicken (Gallus gallus) and human HbAA erythrocytes. Inter. Sci. Res. Jour., 2008, 1 (1): 1 - 4.

18 Noguchi CT, Schechter AN. Inhibition of sickle hemoglobin gelation by amino acids and related compounds. Biochemistry 1978; 17(25): 5455-5459

19 Iwu MM, Igboko AO, Onwubiko H, Ndu UE. Effect of cajaminose from Cajanus cajan on gelation and oxygen affinity of sickle cell haemoglobin. J Ethnopharmacol 1988; 23(1): 99-104

20 Daland GA, Castle WB. A simple and rapid method for demonstrating sickling of the red blood cells; the use of reducing agents. $\boldsymbol{J} \mathbf{L a b}$ Clin Med 1948; 33(9): 1082-1088

21 Brown , B. A. Hematology: Principles and Procedures (5th ed). Lippincott Williams and Wilkins, Philadelphia, USA., 1993, p. 96 97.

22 Duncan, B. D. Multiple range and multiple F test. Biometrics, 1955, 11: 1 - 42.

23 Mohandas N, Feo C. [Quantitative study of changes of the shape of erythrocytes produced by cationic and anionic derivatives of phenothiazine. C R Acad Sci Hebd Seances Acad Sci D 1974; 279(23): 1813-1815

24 Saari JT, Beck JS. Hypotonic hemolysis of human red blood cells: a two-phase process. $\boldsymbol{J}$ Membr Biol 1975; 23(3-4): 213-226 [PMID: 1195346]

25 Rodak, B. F.; Fritsma, G. A.; Keohane E. M. Hematology: Clinical Principles and Applications (4th ed.). Elsevier Saunders, Riverport lane, St. Louis Missouri. 2007, p. 291. 
26 Talaska F. F.; Barnett, D. M. A manual of laboratory and diagnostic tests (8th ed.). Lippincott Williams and Wilkins, Philadelphia, USA. 2008, p. 116.
27 Greer, J. P.; Arber, D. A.; Glader, B.; List, A. F.; Means, R. T. Jr.; Paraskevas, F.; Rodgers, G. M. Wintrobe's Clinical Hematology (12th ed.). Lippincott Williams and Wilkins, Philadelphia, USA. 2009, p. 805. 